\title{
INVESTIGATING THE POTENTIAL FOR BIODIESEL AND BIOACTIVE COMPOUNDS PRODUCTION FROM SOME CYANOBACTERIA
}

\author{
Nermin Adel El Semary \\ Department of Botany and Microbiology, Faculty of Science, Helwan University, \\ Helwan, Egypt.
}

\begin{abstract}
The biotechnological usage of cyanobacteria as a source of clean fuel, vitamin C and bioactive compounds was investigated. Five cyanobacterial strains were screened and tested for the potential of biodiesel production and the quality of biodiesel produced. The inorganic nutritional value of the cyanobacterial strains was estimated through quantifying the strains' mineral content as well as vitamin $\mathrm{C}$ content. To investigate the use of cyanobacteria as a source of bioactive secondary metabolites a phytochemical screening was conducted to test for the presence of alkaloids, flavenoids, saponins and tannins. The different analyses indicated that Aphanizomenon sp., the heterocystous filamentous cyanobacterium contained highest lipid content, best biodiesel quality of more saturated and less unsaturated fatty acid composition, mineral content, vitamin $\mathrm{C}$ and most bioactive secondary metabolites. As a confirmation of the ability of this cyanobacterium to produce secondary metabolites, degenerate primers were used to amplify genetic loci for secondary metabolites. Multiple PCR products were obtained indicating that this isolate represents a rich bioactive compounds source. The study thereby highlights the multiple biotechnological applications of cyanobacteria in general and Aphanizomenon in particular.
\end{abstract}

Key words: Bioactive Compounds, Biodiesel, Gene Mining and Minerals.

\section{Introduction}

Cyanobacteria are oxygenic phototrophs of ubiquitous distribution in all water bodies (Whitton and Potts, 2000). They can live in the most extreme habitats and are equipped with remarkable metabolic activities that rendered them suitable candidates for many biotechnological applications (Thajuddin and Subramanian, 2005). Currently, a new green technology has emerged that is based on the use of microalgal biomass for renewable biodiesel production (Chisti, 2007). This is primarily due to their high photosynthetic efficiency, their rapid growth, their minimal growth requirements and their minimal demand for land and manpower (Chisti, 2007). This description best fits cyanobacteria (blue-

E-mail address: nerminel_semary@yahoo.co.uk 
green algae) as they are able to grow in extreme niches, high salt content, polluted waters and even to fix nitrogen thus being useful as biofertilizers (Whitton and Potts, 2000). All of these characters make cyanobacteria a plausible candidate for biodiesel production.

Among other favourable characters for the biotechnological use of cyanobacteria is their ability to produce a wide range of bioactive compounds which enabled them to out-compete other microorganisms through the antimicrobial effect of those compounds (Skulberg, 2000). The biosynthesis of bioactive compounds proceeds mostly through enzymes largely encoded by two molecular systems; the non-ribosomal peptide synthetases and the polyketide synthases (Ehrenreich $\boldsymbol{e t}$ al., 2005). For the purpose of detecting those genes as indicator of bioactive compounds production, degenerate primers were designed to target those genetic loci (Ehrenreich et al., 2005) in order to verify the potential of natural product biosynthesis by the tested cyanobacteria.

Most of the aforementioned studies available on biotechnological usage of cyanobacteria have mainly focused on one biotechnological aspect. Moreover, studies on the presence of vitamin C (Aaronson et al., 1977) mineral content and phytochemical screening (Scholz and Liebezeit, 2006) are particularly scarce. To explore the potential uses of cyanobacteria in a more comprehensive way, several biotechnological aspects of different cyanobacteria should be evaluated and compared to select for the most promising strain for further studies. Therefore, in the present research we would screen five cyanobacterial strains for the potential of biodiesel production, mineral composition, vitamin $\mathrm{C}$ and secondary metabolites presence and selecting the richest cyanobacterium in those elements for further molecular screening for bioactive compounds production. The various aspects investigated here are meant to provide a holistic picture of the different biotechnological potentials of the isolates studied. This investigation would pave the way in the future to adopt the biorefinery concept that maximizes the exploitation of bio-resources useful in different applications.

\section{Materials and methods}

\section{Cyanobacterial strains and culture conditions}

The five cyanobacterial strains tested were Calothrix PCC7601 (Agardh ex Bornet et Flahault, 1886), Aphanizomenon sp (Morren ex Bornet et Flahault, 1886), Microcystis sp. strain 84/1 (Kutzing, 1883, ex Lemmermann, 1907), Nostoc commune (Vaucher, 1888, ex Bornet et Flahault, 1886) and Spirulina sp. (Turpin ex Gomont, 1882). All of the strains were supplied from Bristol Culture collection, (Courtesy of Professor Paul Hayes, Former Head of the School of Biological Sciences, Faculty of Science, University of Bristol, United Kingdom). 
The morphological description, and growth media and culturing conditions are shown in Table (1).

\section{Extraction and determination of crude lipid}

Cyanobacterial biomass was lypholised, weighed and about $0.1 \mathrm{gm}$ of dry algal material was extracted for $24 \mathrm{hr}$ with chloroform/methanol mixture (2: 1) according to the method used by Rao et al. (1986). The extract was evaporated to constant weight. The remained oily residue was weighed to determine the total crude lipid of each species as a percentage of dry weight.

\section{Biodiesel production}

Oil extraction and preparation of catalyst for trans-estrification proceeded as described by Sharif Hossain and Salleh (2008). The catalyst was mixed with the extracted oil in the presence of methanol. The mixture was kept under continuous shaking for three hours at $300 \mathrm{rpm}$. The mixture was then left to settle for 16 hours. The biodiesel was separated from sediments by separator flask. Biodiesel was washed by $5 \%$ water and was air-dried and biodiesel production was measured by using measuring cylinder and was stored for analysis.

\section{Biodiesel quality analysis (Fatty acid composition)}

Three hundred microlitre of $\mathrm{n}$-hexane was added for each $1 \mathrm{ml}$ of methyl esters (biodiesel). The sample was spun at $3000 \mathrm{rpm}$ for five minutes. The methyl esters in n-hexane layer were analyzed on a Hewlett-Packard Model 5830A gas chromatography. The flow rate of $\mathrm{N}_{2}$ was $40 \mathrm{ml} \mathrm{min}^{-1}$ and the glass column, filled with 3\% SP-2310/ 2\% SP 2300 adsorbed on chromasorb W(80-100 mesh) as stationary phase. Temperature was programmed to increase linearly from $160{ }^{\circ} \mathrm{C}$ to $230{ }^{\circ} \mathrm{C}$ at $30{ }^{\circ} \mathrm{C}$ min. The esters were identified by co-chromatography with standards esters of fatty acids at a concentration of $100 \mu \mathrm{g} \mathrm{ml}^{-1}$ (Gunasekaran and Hughes, 1980).

\section{Macro and micronutrients content}

Dried cyanobacterial biomass was digested using acid mixture of perchloric, nitric and sulphuric acids. For macronutrients, measurements were performed as follows: potassium, sodium and calcium were photometrically measured by flame Emission Unit (Jenway, PEP 7). Iron, zinc, manganese, copper and magnesium were measured photometrically by Atomic Absorption Units (GBC 932 AA) (Chapman and Pratt, 1978).

\section{Vitamin $C$ content}

Lyophilised cyanobacterial filaments $(1 \mathrm{~g})$ were extracted in $80 \%(\mathrm{v} / \mathrm{v})$ methanol and vitamin C content was quantified by its UV absorbance at $254 \mathrm{~nm}$ using reverse phase HPLC on a C18 column (Perkin-Elmer Phenomenex HPLC, C18 Ultracarb 7.0 Column ODS 20, dimension $250 \times 4.6 \mathrm{~mm}$ ). The mobile phase 
was methanol: water (97:3), added under isocratic conditions with a flow rate of $0.5 \mathrm{ml} \mathrm{min}{ }^{-1}$. The identity and quantity of vitamin $\mathrm{C}$ was confirmed by cochromatography of known concentration of authentic standards (Jaffe, 1984).

\section{Phytochemical screening}

Approximately one gram of lypholised sample was extracted in $80 \%$ ethanol for two days. The extract was used for the following tests for:

a) Tannins, the development of a yellowish green colour in the presence of ferric chloride indicates tannins presence (Claus, 1967).

b) Saponins are detected by their ability to develop a froth that is stable for a period of time (Wall et al., 1954)

c) Alkaloids presence is confirmed by the occurrence of turbidity or precipitation with Mayer's reagent (Scholz and Liebezeit, 2006).

d) Flaveniods presence is indicated by the development of orange to red color when magnesium ribbon is added to the alcoholic extract followed by dropwise addition of concentrated $\mathrm{HCl}$ (Scholz and Liebezeit, 2006).

Molecular screening for secondary metabolites biosynthetic genes (NRPS).

The primers designed by Ehrenreich et al. (2005) were used: the forward primer MTF2 (5'-GCNGGYGGYGCNTAYGTNCC-3') and the reverse primer MTR (5' CCNCGDATYTTNACYTG-3'). Genomic DNA was extracted according to the method detailed by El Semary (2005) which was modified from Smoker and Baruum (1988). Briefly, $1 \mathrm{ml}$ of culture was pelleted by centrifugation, and the pellet was resuspended in $500 \mu \mathrm{l}$ of a buffer composed of $\{50 \mathrm{mM}$ Tris- $\mathrm{HCl}(\mathrm{pH}$

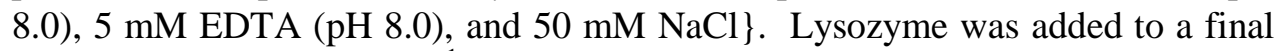
concentration of $1 \mathrm{mg} \mathrm{ml}^{-1}$ in the presence of sucrose and the solution was incubated at $37^{\circ} \mathrm{C}$ for 2 hours with occasional mixing. After the addition of $10 \mu \mathrm{l}$ of proteinase $\mathrm{K}\left(10 \mathrm{mg} \mathrm{ml}^{-1}\right)$ and $20 \mu \mathrm{l}$ of $10 \%$ (w/v) sodium dodecylsulfate, the mixture was incubated at $55{ }^{\circ} \mathrm{C}$ for one hour or until the solution cleared (complete cell-lysis). The solution was chilled on ice and extracted with an equal volume of phenol-chloroform-isoamylalcohol (25: 24: $1 \mathrm{v} / \mathrm{v} / \mathrm{v})$. The organic extraction was repeated, and the clear colourless supernatant was added to one tenth of its volume of $3 \mathrm{M}$ sodium acetate. Total genomic DNA was precipitated by incubation with an equal volume of isopropanol at $-20{ }^{\circ} \mathrm{C}$ for one hour followed by centrifugation at $4500 \mathrm{x}$ g for $10 \mathrm{~min}$ at room temperature, washed with $70 \%$ ethanol $(\mathrm{v} / \mathrm{v})$, vacuum dried and re-dissolved in $10 \mathrm{mM}$ Tris, $1 \mathrm{mM}$ EDTA (pH 8.0) and kept at $4{ }^{\circ} \mathrm{C}$ overnight. Following reprecipitation using isopropanol, rinsing using $70 \%$ ethanol and vacuum drying, the final pellet was dissolved in sterile distilled water and stored at $4^{\circ} \mathrm{C}$. The NRPS genetic loci were initially amplified using SuperTaq Polymerase enzyme with SuperTaq buffer 
(H.T. Biotechnology Ltd, UK) without addition of Mg. The primers were used at a final concentration of $0.5 \mu \mathrm{M}$ in $25-\mu \mathrm{L}$ reactions, which also contained $0.5 \mathrm{U}$ of Taq polymerase, $200 \mu \mathrm{M}$ Deoxyribo-Nucleotide-5'-triphosphate (dNTPs) (Promega, United Kingdom) and 1x Supertaq buffer. The reactions contained 2 $\mu 1$ of genomic DNA as a template. The PCR amplification protocol was as follows: initial denaturation cycle at $94^{\circ} \mathrm{C}$ for $5 \mathrm{~min}$; main amplification stage $94^{\circ} \mathrm{C}, 1 \mathrm{~min} ; 50{ }^{\circ} \mathrm{C}, 1 \mathrm{~min} ; 72^{\circ} \mathrm{C}$ for 35 cycles and a final elongation cycle at $72^{\circ} \mathrm{C}$ for7 min using thermal cycler (G storm, UK ).

The PCR products were run on agarose gel $1.5 \%(\mathrm{w} / \mathrm{v})$ agarose in $1 \mathrm{x}$ TAE buffer (Sambrook et al., 1989). Five microlitre of the PCR products were mixed with $1 \mu$ l of loading buffer $(0.25 \%(\mathrm{w} / \mathrm{v})$ bromophenol blue, $0.25 \%(\mathrm{w} / \mathrm{v})$ xylene cyanol FF, 15\% (w/v) Ficoll x 400) prior to separation. A 100 bp size marker ladder (Gibco) was run through the gels alongside the samples. The gel was poststained in ethidium in SYBR Gold ${ }^{\circledR}\left(0.5 \mu 1\right.$ of $10^{4} \mathrm{x}$ strength stock in $5 \mathrm{ml}$ TAE) for at least $20 \mathrm{~min}$ and then destained in water for $5 \mathrm{~min}$. The bands were visualized under ultraviolet light using Gel Doc system (UVP, USA).

\section{Results}

Aphanizomenon sp. showed the highest lipid content followed by Calothrix PCC7601, Nostoc commune and Spirulina sp. Microcystis sp. 84/1 showed lowest lipid content (Table 1).

Table (1): The growth conditions, morphology and lipid content of the isolates tested.

\begin{tabular}{|c|c|c|c|c|}
\hline Isolate & Morphology & Growth medium & Growth conditions & $\begin{array}{c}\text { Lipid } \\
\text { content }\end{array}$ \\
\hline $\begin{array}{c}\text { Aphanizomenon } \\
\text { sp. }\end{array}$ & $\begin{array}{l}\text { Needle-like } \\
\text { heterocystous filaments, } \\
\text { Section four** }\end{array}$ & $\begin{array}{c}\text { BG11 } \\
\text { Rippka } \text { et al. } \\
(1979)\end{array}$ & $\begin{array}{l}\text { 12/12 L/D cycle, } \\
\text { Temperature } 20^{\circ} \mathrm{C}, \\
\text { light intensity } \\
15 \mu \mathrm{mol} \mathrm{m} \mathrm{m}^{-2}\end{array}$ & $31 \%$ \\
\hline $\begin{array}{l}\text { Nostoc } \\
\text { commune }\end{array}$ & $\begin{array}{l}\text { Heterocystous filaments } \\
\text { with bead-like cells, } \\
\text { hormogonia producer, } \\
\text { Section four }\end{array}$ & $\begin{array}{c}\text { Anabaena medium } \\
\text { Walsby and } \\
\text { Booker (1980) }\end{array}$ & $\begin{array}{c}12 / 12 \mathrm{~L} / \mathrm{D} \text { cycle } \\
\text { Temperature } 20{ }^{\circ} \mathrm{C} \\
\text { light intensity } \\
15 \mu \mathrm{mol} \mathrm{m}{ }^{-2} \mathrm{~s}^{-1}\end{array}$ & $28 \%$ \\
\hline $\begin{array}{c}\text { Microcystis sp. } \\
84 / 1\end{array}$ & $\begin{array}{c}\text { Unicellular but usually } \\
\text { found in aggregates } \\
\text { Section one }\end{array}$ & $\begin{array}{c}\text { BG11 } \\
\text { Rippka et al. } \\
(1979)\end{array}$ & 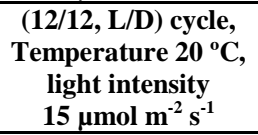 & $18 \%$ \\
\hline Spirulina sp. & $\begin{array}{c}\text { Non-heterocystous spiral } \\
\text { filaments } \\
\text { Section three }\end{array}$ & $\begin{array}{c}\text { BG11 } \\
\text { Rippka } \text { et al. } \\
(1979)\end{array}$ & $\begin{array}{l}(12 / 12, \mathrm{~L} / \mathrm{D}) \text { cycle, } \\
\text { Temperature } 20^{\circ} \mathrm{C}, \\
\text { light intensity } \\
30 \mu \mathrm{mol} \mathrm{m}{ }^{-2} \mathrm{~s}^{-1}\end{array}$ & $24 \%$ \\
\hline $\begin{array}{l}\text { Calothrix } \\
\text { PCC7601 }\end{array}$ & $\begin{array}{l}\text { Filamentous but lack } \\
\text { heterocysts due to } \\
\text { mutation, hormogonia } \\
\text { producer, Section four }\end{array}$ & $\begin{array}{c}\text { BG11 } \\
\text { Rippka } \text { et al. } \\
(1979)\end{array}$ & $\begin{array}{l}(6 / 18, \mathrm{~L} / \mathrm{D}) \text { cycle, } \\
\text { Temperature } 30^{\circ} \mathrm{C}, \\
\text { light intensity } \\
15 \mu \mathrm{mol} \mathrm{m} \mathrm{m}^{-2} \mathrm{~s}^{-1}\end{array}$ & $30 \%$ \\
\hline
\end{tabular}

**Note: Sections are classified according to Rippka et al. (1979) based on cell division, morphology and developmental stages. 


\section{Biodiesel quality}

The fatty acid composition of the biodiesel obtained showed the dominance of polyunsaturated omega-6- gamma C18-linoleic acid both in Spirulina sp. and Microcystis sp. 84/1. Aphanizomenon sp. on contrary, showed lowest content of this fatty acid as well as lowest content of the di-unsaturated oleic acid. Saturated palmitic acid was highest in Calothrix PCC7601 and Aphanizomenon sp. and lowest in Microcystis. Palmetoleic acid was lowest in Microcystis (Table 2)

Table (2): Fatty acid composition of the cyanobacterial strains expressed as relative percentage to total fatty acid.

\begin{tabular}{cccccc}
\hline Fatty acid & $\begin{array}{c}\text { Calothrix } \\
\text { PCC7601 }\end{array}$ & $\begin{array}{c}\text { Aphanizomenon } \\
\text { sp. }\end{array}$ & $\begin{array}{c}\text { Microcystis } \\
\text { sp.84/1 }\end{array}$ & $\begin{array}{c}\text { Nostoc } \\
\text { commune }\end{array}$ & $\begin{array}{c}\text { Spirulina } \\
\text { sp. }\end{array}$ \\
\hline Caproic & $\mathbf{1 0 . 7 4 \%}$ & $\mathbf{0 4 . 2 1 \%}$ & ND** & $\mathbf{0 5 . 9 0 \%}$ & ND \\
\hline Lauric & $\mathbf{0 2 . 6 3 \%}$ & $\mathbf{0 0 . 9 2 \%}$ & ND & $\mathbf{0 1 . 9 3 \%}$ & $\mathbf{0 0 . 3 5 \%}$ \\
\hline Myristic & $\mathbf{0 1 . 2 5 \%}$ & $\mathbf{0 3 . 1 7 \%}$ & $\mathbf{0 4 . 2 2 \%}$ & $\mathbf{0 0 . 7 4 \%}$ & $\mathbf{0 0 . 4 8 \%}$ \\
\hline Palmitic & $\mathbf{6 0 . 8 0 \%}$ & $\mathbf{5 7 . 5 \%}$ & $\mathbf{1 5 . 1 0 \%}$ & $\mathbf{2 8 . 7 1 \%}$ & $\mathbf{2 2 . 1 1 \%}$ \\
\hline Palmetoleic & $\mathbf{1 1 . 0 6 \%}$ & $\mathbf{2 8 . 2 2 \%}$ & $\mathbf{0 3 . 1 8 \%}$ & $\mathbf{3 7 . 0 6 \%}$ & $\mathbf{0 3 . 1 8 \%}$ \\
\hline Stearic & $\mathbf{0 7 . 2 9 \%}$ & $\mathbf{0 4 . 8 1 \%}$ & $\mathbf{0 5 . 4 3 \%}$ & $\mathbf{1 7 . 4 8 \%}$ & $\mathbf{0 0 . 2 3 \%}$ \\
\hline Oleic & $\mathbf{0 3 . 3 8 \%}$ & $\mathbf{0 0 . 7 2 \%}$ & $\mathbf{2 4 . 3 0 \%}$ & $\mathbf{0 6 . 4 7 \%}$ & $\mathbf{0 6 . 1 1 \%}$ \\
\hline$\gamma$-Linoleic & $\mathbf{0 3 . 3 8 \%}$ & $\mathbf{0 0 . 7 0 \%}$ & $\mathbf{4 3 . 8 4 \%}$ & $\mathbf{0 1 . 7 1 \%}$ & $\mathbf{4 7 . 3 9 \%}$ \\
\hline \multicolumn{2}{c}{$*$ ND. Not determined. } & & & &
\end{tabular}

**ND. Not determined.

\section{Nutritional aspects}

Results showed that the richest mineral composition was that of Aphanizomenon sp. which showed highest content of potassium, iron and manganese followed by Microcystis which also showed highest copper, zinc and calcium content. Highest sodium content was for Nostoc commune (Table 3).

Table (3): Mineral composition and vitamin $\mathrm{C}$ content of the cyanobacterial strains (\% of dry wt for K. Ca and Na).

\begin{tabular}{cccccc}
\hline Elements & $\begin{array}{c}\text { Calothrix } \\
\text { PCC7601 }\end{array}$ & $\begin{array}{c}\text { Aphanizomenon } \\
\text { sp. }\end{array}$ & $\begin{array}{c}\text { Microcystis } \\
\text { sp 84/1 }\end{array}$ & $\begin{array}{c}\text { Nostoc } \\
\text { commune }\end{array}$ & $\begin{array}{c}\text { Spirulina } \\
\text { sp. }\end{array}$ \\
\hline K\% & $\mathbf{0 3 . 0 0 \%}$ & $\mathbf{1 3 . 8 \%}$ & $\mathbf{0 7 . 3 0 \%}$ & $\mathbf{0 3 . 2 0 \%}$ & $\mathbf{0 0 . 5 0 \%}$ \\
\hline Ca\% & $\mathbf{0 0 . 3 0 \%}$ & $\mathbf{1 . 2 \%}$ & $\mathbf{0 4 . 5 0 \%}$ & $\mathbf{0 0 . 5 0 \%}$ & $\mathbf{0 2 . 9 0 \%}$ \\
\hline Na\% & $\mathbf{0 5 . 0 0 \%}$ & $\mathbf{4 . 7 \%}$ & $\mathbf{0 9 . 8 0 \%}$ & $\mathbf{2 1 . 0 0 \%}$ & $\mathbf{0 3 . 1 0 \%}$ \\
\hline Fe ppm & $\mathbf{8 8 . 1 7}$ & $\mathbf{1 5 2 8}$ & $\mathbf{5 3 3 . 0 1}$ & $\mathbf{2 9 . 0 0}$ & $\mathbf{0 2 . 7 0}$ \\
\hline Mn ppm & $\mathbf{0 0 . 7 0}$ & $\mathbf{1 4 5 2}$ & $\mathbf{1 3 . 8 7}$ & $\mathbf{0 3 . 4 1}$ & $\mathbf{0 1 . 6 8}$ \\
\hline Zn ppm & Traces & $\mathbf{1 2 . 0 0}$ & $\mathbf{4 1 . 6 2}$ & $\mathbf{0 9 . 4 0}$ & $\mathbf{0 0 . 2 4}$ \\
\hline Cu ppm & Traces & Traces & $\mathbf{0 8 . 0 9}$ & Traces & $\mathbf{0 0 . 0 4}$ \\
\hline $\begin{array}{c}\text { Vitamin C } \\
(\mu \text { g gm d.wt. }\end{array}{ }^{-1}$ ) & 2 & 26 & \multirow{2}{*}{$\mathbf{0 . 0 4}$} & $\mathbf{0 . 2}$ & 7 \\
\hline
\end{tabular}


Vitamin $\mathrm{C}$ was detected in a considerable quantity in Aphanizomenon sp. (Figure 1) whereas it was hardly detected in Microcystis sp. 84/1 (Table 3).

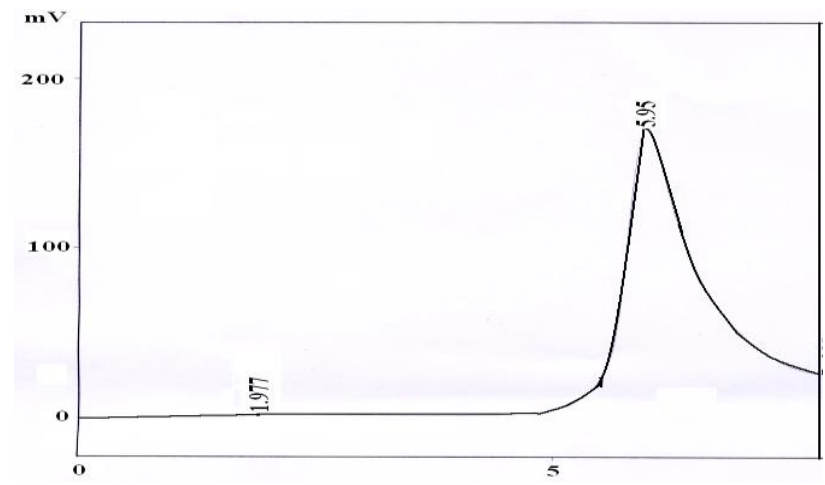

Figure (1): HPLC detection of vitamin C from Aphanizomenon sp.

\section{The phytochemical screening for secondary metabolites}

The phytochemical screening revealed the absence of tannins in all cyanobacterial strains tested. Aphanizomenon sp. was the richest cyanobacterium with secondary metabolites where saponins, flavenoids and alkaloids were all present. On contrary, Microcystis sp.84/1 lacked most of these compounds except for alkaloids (Table 4).

Table (4): Phytochemical screening for secondary metabolites.

\begin{tabular}{cccccc}
\hline $\begin{array}{c}\text { Secondary } \\
\text { metabolites }\end{array}$ & $\begin{array}{c}\text { Calothrix } \\
\text { PCC7601 }\end{array}$ & $\begin{array}{c}\text { Aphanizomenon } \\
\text { sp. }\end{array}$ & $\begin{array}{c}\text { Microcystis } \\
\text { sp. 84/1 }\end{array}$ & $\begin{array}{c}\text { Nostoc } \\
\text { commune }\end{array}$ & $\begin{array}{c}\text { Spirulina } \\
\text { sp. }\end{array}$ \\
\hline Saponins & $-\mathrm{ve}$ & $+\mathrm{ve}$ & $-\mathrm{ve}$ & $+\mathrm{ve}$ & $+\mathrm{ve}$ \\
\hline Tannins & $-\mathrm{ve}$ & $-\mathrm{ve}$ & $-\mathrm{ve}$ & $-\mathrm{ve}$ & $-\mathrm{ve}$ \\
\hline Flavenoids & $-\mathrm{ve}$ & $+\mathrm{ve}$ & $-\mathrm{ve}$ & $-\mathrm{ve}$ & $-\mathrm{ve}$ \\
\hline Alkaloids & $+\mathrm{ve}$ & $+\mathrm{ve}$ & $+\mathrm{ve}$ & $+\mathrm{ve}$ & $+\mathrm{ve}$ \\
\hline
\end{tabular}

Molecular screening for secondary metabolites biosynthetic genes (NRPS) from Aphanizomenon sp.

One distinct clear band appeared of about size of $500 \mathrm{bp}$ with other faint bands observed but not clearly discernible when primers specific for the NRPS genetic loci were used (Figure 2). 


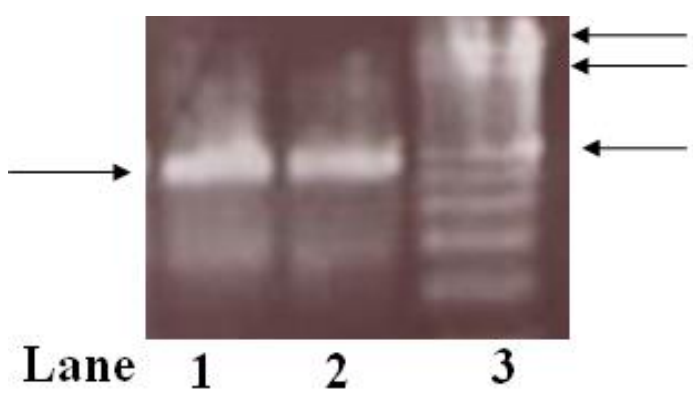

Figure (2): Gel-electrophoresis photo showing PCR amplicon(s) using NRPS primers. Lanes 1 and 2 are replicates of the PCR amplicons where Lane three is 100 bp ladder marker.

\section{Discussion}

Biodiesel production from algal biomass has emerged as one of the most promising renewable energy sources. The high photosynthetic efficiency, the large biomass produced, the modest growth requirements, the carbon neutral quality of fuel obtained, the pollution-free combustion of fuel, the useful byproducts all merited the use of this new clean technology for energy generation (Chisti, 2007; Sharif Hossain and Salleh, 2008). However, more research needs to be done to explore the algal taxa that qualify for use in biodiesel production. In the present study, we addressed this point by investigating the biotechnological potential of five cyanobacterial strains belonging to different cyanobacterial groups. The lipid content was determined to select for the isolate with highest lipid content (precursors of biodiesel). Of all strains tested, Aphanizomenon sp. showed the highest lipid content. Analysis of the composition of biodiesel (methyl ester produced) was performed. Polyunsaturated C-18 linolenic fatty acid was the dominant fatty acid in Spirulina and Microcystis. Unlike what (Kenyon, 1972) reported that unicellular types of cyanobacteria lack polyunsaturated fatty acids, this type of polyunsaturated fatty acids was major in the fatty acid composition of Microcystis. This finding coincided with what Krüger $\boldsymbol{e t}$ al. (1995) reported that Microcystis isolates are characterised by a high content of polyunsaturated fatty acids and a low content of palmitoleate. On the other hand, Aphanizomenon sp. recorded the lowest content of this polyunsaturated fatty acid on contrary to its high content of Calothrix PCC7801. This difference in fatty acid content between the two filamentous cyanobcteria is not surprising. Cyanobacterial filamentous strains mostly contain high contents of di-unsaturated and polyunsaturated fatty 
acids (Sato and Murata, 1982). However, some may possess very minor concentrations of polyunsaturated fatty acids. Lack of polyunsaturated fatty acids may be wide-spread feature among filamentous cyanobacteria (Oren et al., 1985). Fatty acids, apart from being useful chemotaxonomic markers as well as nutritional and structural elements (Madigan et al., 2000) are the precursors of biodiesel (Fatty acid methyl esters). According to Chisti (2007), the quality of biodiesel is better when less polyunsaturated fatty acids are found. Therefore, Aphanizomenon sp. seems to top the other cyanobacteria with regard to lipid content and the quality of biodiesel produced.

When cyanobacterial isolates were screened for their mineral content, Aphanizomenon sp. showed a remarkable content of iron and manganese as well as being highest in its potassium content. Manganese is of rather limited occurrence (Baptista and Vascocelos, 2006) and its presence in this cyanobacterium in abundance together with iron offers opportunities for the use of this cyanobacterium as a supplement in mineral nutrition or as foliar spray. In addition, the presence of more potassium and less sodium content is nutritionally most favourable (Falquet, 2006). The importance of potassium in mineral nutrition stems from the fact that it functions in osmotic regulation and maintenance of electrochemical environment within the cell and its nature as a mobile element makes it easily distributed during active growth (Nason and McElroy, 1963). Algal extracts rich in potassium and iron and other nutrients are excellent foliar sprays (Abd El Hameed, 2007). Nutrients content from the other cyanobacterial strains tested were less abundant, only Microcystis showed highest content of calcium and copper in addition to considerable content of iron and potassium. Vitamin $\mathrm{C}$, another important nutritional supplement, was detected in a considerable quantity in all cyanobacterial tested except for Microcystis sp. Aphanizomenon was highest in its vitamin C content followed by Spirulina, Nostoc and Calothrix. There is no clear relation in literature about mineral content and biodiesel quality, however, some standards for high quality biodiesel are found in this website http://www.iges.or.jp/en/bf/pdf/activity20090204/session3/Haerudin.pdf, in which certain values of sulphur and phosphate are to be observed for the production of high quality biodiesel.

Vitamin $\mathrm{C}$ is a powerful antioxidant that protects cellular membranes and structures against oxidative damage as a result of free radicals and reactive oxygen species (Buettner, 1993). Its water solubility and antioxidant activity renders it a plausible component in supplements and foliar sprays.

To further explore the presence of bioactive compounds, phytochemical screening for secondary metabolites was conducted. The tests confirmed the 
presence of saponins, alkaloids, flavenoids and absence of tannins. Aphanizomenon sp. and Nostoc commune were the richest sources of secondary metabolites being only negative for tannins in addition to absence of flavenoids from Nostoc commune.

So far, the tests performed have confirmed the richness of Aphanizomenon sp. of useful products/nutrients. Nevertheless, the presence of the genetic domains within Aphanizomenon sp. responsible for bioactive metabolites was also tested. Molecular evidence for that was proved using primers specific for genes coding non ribosomal peptide synthetase, the enzymatic systems responsible for several cyanobacterial secondary metabolites (Ehrenreich $\boldsymbol{e t}$ al., 2005). This "gene mining"strategy was successfully used by Ehrenreich $\boldsymbol{e t}$ al. (2005) and Barrios-Llerena et al. (2007) for exploring the presence of genes responsible for bioactive compounds production. Ehrenreich et al. (2005) also reported that filamentous cyanobacteria are very rich source of natural products and confirms that the cyanobacterium Aphanizomenon is a rather promising candidate for future biotechnological applications.

Taken all together, cyanobacteria have multiple biotechnological usages. They are rich sources of biofuel, bioactive compounds and vitamins. Further studies should address the production of these products on an industrial scale through adopting biorefinery concept that exploits all assets of biological material. Nonetheless, it is of a paramount importance to preselect the promising isolates that are rich in valuable products, as evidenced by both biochemical and genetic tests, to allow for this biotechnological exploitation to happen. Given the fragmentary nature of the current information on biofuels/bioproducts from cyanobacteria, the present study was dedicated to fill in some of the gaps in knowledge about those products. This information is vital for the construction of elementary biorefinery systems applicable on cyanobacteria.

\section{References}

Aaronson, S.; Dhawale, S.W.; Patni, N. J.; DeAngelis, B.; Frank, O. and Baker, H. (1977). The cell content and secretion of water-soluble vitamins by several Freshwater algae. Arch. Microbiol., 112: 57-59.

Abd El Hameed, O. (2007). Studies on some Egyptian seaweeds and their effect in improving the productivity of Vicia faba and Triticum vulgaris. Ph.D. Thesis, Department of Botany and Microbiology, Faculty of Science, Helwan University, Egypt. pp.187-189.

Barrios-Llerena, M. E.; Burja, A. M. and Wright P. C. (2007). Genetic analysis of polyketide synthase and peptide synthetase genes in cyanobacteria as a mining tool for secondary metabolites. J. Indust. Microbiol. Biotechnol., 34: 443-456. 
Baptista, M. S. and Vascocelos, M. T. (2006). Cyanobacteria metal interactions: requirements, toxicity, and ecological implications. Cri. Rev. Microbiol., 32: 127-137.

Buettner, G. R. (1993). The pecking order of free radicals and antioxidants: lipid peroxidation, alpha-tocopherol, and ascorbate. Arch. Biochem. Biophy., 300 (2): 535-543.

Chisti, Y. (2007). Biodiesel from microalgae. Biotechnol. Adv., 25:294-306.

Chapman, H. D. and Pratt, P. F. (1978). Methods of analysis for soil, plants and water. $2^{\text {nd }}$ Edition. Chapter 5. Water analysis. University of California Press, Berkeley, CA., USA. pp. 157-179.

Claus, E. R. (1967). Pharmacognosy $5^{\text {th }}$ Ed. Henry Kimpton Co. Inc., London. pp.223.

Ehrenreich, I. M.; Waterbury, J. B. And Webb E. A. (2005) Distribution and diversity of natural product genes in marine and freshwater cyanobacterial cultures and genomes. Appl. Environ.Microbiol., 71 (1):7401-7413.

El Semary, N. A. (2005). Anabaena and associated bacteria: molecular approaches to studying community structure and taxonomy. $\mathrm{Ph} \mathrm{D}$ thesis, Faculty of Science, University of Bristol, UK. pp.48-49.

Falquet, J. (2006). Nutritional aspects of Spirulina. Antenna Technologies. http://www.antenna.ch/en/documents/Aspect Nut_UK.pdf.

Gunasekaran, M. and Hughes, W. T. (1980). Gas liquid chromatography; a rapid method for identification of different species of Candida. Mycologia, 72: 505-511.

Jaffe, G. M. (1984). Ascorbic acid. In: Kirk-Othmer Encyclopedia of Chemical Technology. $3^{\text {rd }}$ Edition. (Ed. Grayson M), published by M. John Wiley and Sons, New York, Vol. 24, pp. 917.

Kenyon, C. N. (1972). Fatty acid composition of unicellular strains of blue-green algae. J. Bacteriol., 109: 827- 834.

Krüger, G. H. J.; De Wet, H.; Kock, J. L. F. and Pieterse, A. J. H. (1995). Fatty acid composition as a taxonomic characteristic for Microcystis and other coccoid cyanobacteria (blue-green alga) isolates. Hydrobiologia, 308:145-151.

Madigan, M. T.; Martinko, J. M. and Parker, J. (2000). Brock Biology of microorganisms. $9^{\text {th }}$ Edition. Prentice-Hall International Ltd, London, UK. Pp.521 and 625.

Nason, A. and McElroy, W.D. (1963). Modes of action of the essential mineral elements. In: Streward FC. (ed.) Plant Physiology, vol.3. Inorganic nutrition of plants, Academic Press, New York, pp.451.

Oren, A.; Fattom, A.; Padan, E. and Tietz A. (1985). Unsaturated fatty acid composition and biosynthesis in Oscillatoda limnetica and other cyanobacteria. Arch. Microbiol., 141:138-142. 
Rao, P. P. S.; Rao, S. and Kramer, S. M. (1986). Antibacterial substances from brown algae, II. Efficiency of solvents in the evaluation of antibacterial substances from Sargassum johnstonii. Bot. Mar., 29: 503-507.

Rippka, R.; Deruelles, J.; Waterbury, J. B.; Herdman, M. and Stanier, R. Y. (1979). Generic assignments, strain histories and properties of pure cultures of Cyanobacteria. J. General Microbiol., 111:1-61.

Sambrook, J., Fritsch, E. F. and Maniatis, T. (1989). Molecular cloning: Laboratory Manual, $2^{\text {nd }}$ edition. Cold spring Harbour, NY, Cold Spring Harbour Laboratory. USA. Pp. 6-9.

Sato, N. and Murata, N. (1982). Lipid biosynthesis in the blue-green alga, Anabaena variabilis. II. Fatty acids and lipid molecular species. Biochim. Biophys. Acta., 71:279-289.

Scholz B. and Liebezeit G. (2006). Chemical screening for bioactive substances in culture media of microalgae and cyanobacteria from marine and brackish water habitats: First Results. Pharma. Biol., 44(7):544-549.

Sharif Hossain, A. B. M. and Salleh, A. (2008). Biodiesel fuel production from algae as renewable energy. Amer. J. Biochem. Biotechnol., 4 (3):250-254.

Skulberg, O. M. (2000). Microalgae as a source of bioactive molecules experience from cyanophyte research. J. Appl. Phycol., 12:341-348.

Smoker, J. A. and Baruum, S. R. (1988). Rapid small-scale DNA isolation from filamentous cyanobacteria. FEMS Microbiol. Lett. 56:119-222.

Thajuddin, N.; Subramanian, G. (2005). Cyanobacterial biodiversity and potential applications in biotechnology. Curr.Sci., 89 (1):47-57.

Wall, M. E.; Kreider, M. M.; Kemson, C. F.; Eddy, C. R.; Williaman, J. J.; Corell, D. S. and Gentry, H.S. (1954). Steroidal sapogenins. VII-Survey of plants for steroidal sapogenins and other constituents. J. Amer. Pharma. Soc., 43:1-3.

Walsby, A. E. and Booker, M. J. (1980). Changes in buoyancy of a planktonic blue-green alga in response to light intensity. Bri. Phycol. J., 15:311-319.

Whitton, B. A. and Potts, M. (2000). Freshwater blooms. In: The ecology of cyanobacteria. Their diversity in time and space (B.A. Whitton, ed.). Kluwer Academic Publishers. Dordrecht, The Netherlands, pp 149-194.

Web site of biodiesel quality: http://www.iges.or.jp/en/bf/pdf/activity20090204/session3/Haerudin.pdf, 


\section{تقصى قدرة بعض السيانوبكتريا على انتاج الديزل الحيوى و المواد ذات النشاط الحيوي

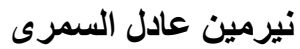 \\ قسم النبات و المبكروبيولوجى ـ كلية العلوم- جامعة حلوان.
}

تم تقصى الاستخدام البيو تكنولوجى للسبانوبكتريا كمصدر للوقود النظيف و فيتامين "ج" و والمواد

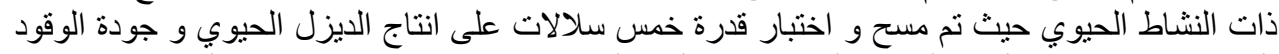

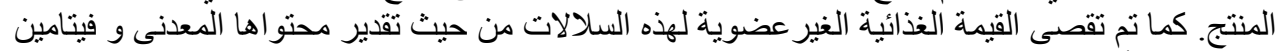

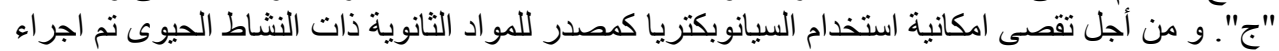

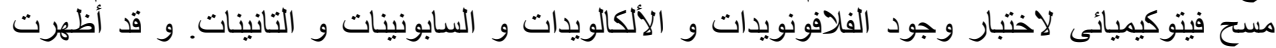

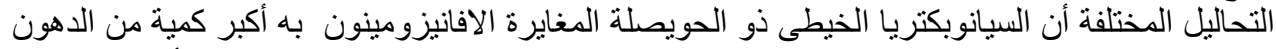

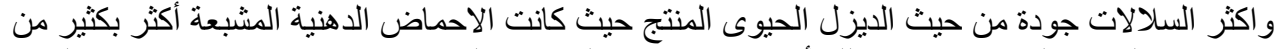

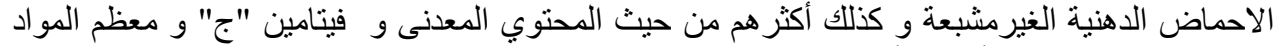

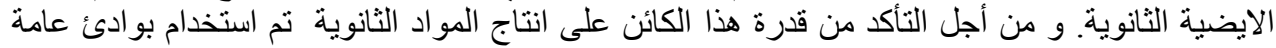

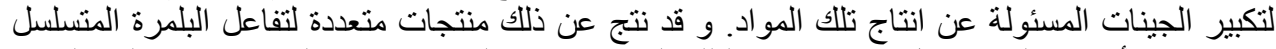

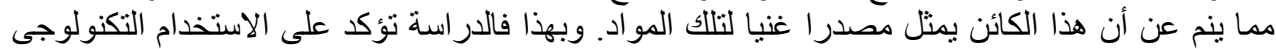

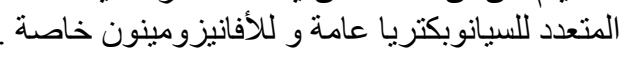

